\title{
The Influence of Tax Comprehension, Tax Awareness and Tax Sanctions Toward Tax Obedience of SME's
}

\author{
Yulita Zanaria $^{1 *}$, Artha Ayu Lestari ${ }^{1}$ \\ ${ }^{I}$ Department of Accounting, Muhammadiyah University Metro, Lampung, Indonesia \\ "Corresponding author. Email: yualita.kenanga@gmail.com
}

\begin{abstract}
This study aims to analyze the effect of understanding taxpayer awareness of Taxpayers and tax sanctions on taxpayer compliance SME'S who conduct online business activities in the city of Metro. This type of research is quantitative research. Sources of the Data in this study are primary and secondary data Obtaining the data by the data from the results of the questionnaire. The questionnaire was given to a sample of 97 SME's Taxpayers in the city of Metro who conduct online business activities through the website, Twitter, Facebook, Instagram, Tokopedia or other platforms. Based on research results Understanding Taxpayers have a significant effect on the compliance of SME's Taxpayers in STO Metro. Tax Awareness Affects the compliance of SME's Taxpayers in STO Metro. Awareness of Taxpayers understands the taxpayer's tax system used, knows the function of taxes as a source of state revenue used for state financing, and understands taxation regulations regarding filing tax returns and paying tax obligations. So that the higher awareness of Taxpayers will Increasingly Increase of tax compliance of SME'S. Tax sanctions do not Affect the compliance of SME'S Taxpayers in STO Metro. So, the Tax Sanctions set by the Government have not gone well, so that the tax sanctions do not Affect the compliance of tax payers of SME's.
\end{abstract}

Keywords: understanding taxpayers, taxpayer awareness, tax sanctions, taxpayer compliance

\section{INTRODUCTION}

The development of information technology has made various changes in the joints of people's lives. Society has now been spoiled by various forms of technology that Allows Them to perform everyday activities. Especially in trade transactions known to a model of that is more popular and Become a trend among the public, Including in Indonesia. This form of trading is known as an online business. Online business transactions are facilitated by an electronic system known as the Internet [1].

The development of Internet usage in Indonesia is a challenge for marketers to Utilize the Internet as a tool in the implementation of marketing strategies. Nielsen [2] show that in the last five years, the general Internet consumption in Indonesia Increased from $8 \%$ to $21 \%$ with the frequency of use has Increased as well. Internet users who use the internet every day the most significant increase is, from just $3 \%$ to $25 \%$. The survey results Also Showed that $80 \%$ of internet users are predicting will buy something online within the next 6 months. The survey results show that today the use of the Internet to conduct online transactions Widely practiced by the company.

Nielsen [2] mentions that the growing number of Internet users who shop and online business due to the fact that consumers have the knowledge Increasingly, more access to information and want the offer section that suit Reviews their needs. In terms of value, consumers are willing to pay more for high-quality materials. Increasingly consumers are demanding quality Also along with the increasing purchasing power and bustle society. In addition, the Nielsen Newsletter (2010) in the "More Practical Shopping on the
Internet" Also survey mentions that the cause of the increasing trend of consumers to shop online is the convenience and practicality.

The trend is welcomed by marketers by implementing online marketing strategies, especially in terms of promotion in order to communicate the product / service, price, and location where buyers can get the products / services offered. Marketing strategy marketing mix that combines the many displayed by companies via the Internet. In addition to promotion. Also, the company conducts online sales. It is evident from the many online stores (online shop) offering a variety of products through websites, blogs, and social networking.

Business transactions online has now become the subject of the conversation is Often used by the taxpayer in conducting its business activities. This is Because this technology become a means favorable to the taxpayer MSME in conducting business activities. In contrast to the usual trade transactions, business transactions online have many complex problems. One of them is the business of buying and selling products through the Internet or online in the last few years is growing very rapidly, but not many businesses that report Reviews their business taxes [3].

The problem of online business transactions is taxed difficult, Because the Self-assessment System adopted by the Indonesian taxation system that Gives Credence to the taxpayer, put more pressure on the taxpayer's own awareness to pay taxes on income earned from the business. Because this is in the online business transactions only accompanied by evidence showing money transfers shift of money from the account to the account of the first party the other party, and did not show proof of purchase transactions are taxed. 
Tax revenue in Indonesia is very low. One reason is Because The level of tax compliance is becoming increasingly. Research on taxpayer compliance have been Carried out. According to Pratt [3] tax compliance is mandatory tax prescribed by the Director General of Taxation as a taxpayer who meets Certain criteria can be given a preliminary return of overpaid taxes. According to Suryadi [4] tax compliance established by the dimensions of the tax inspection, enforcement and compensation tax. The purpose was to test the examination of tax compliance in implementing the tax. Increase tax compliance obligations state and in turn will increase of the amount of the tax ratio.

In the self-assessment system of tax collection system of consciousness taxpayer, had to be Considered in an effort to increase of the level of tax compliance. Consciousness Possessed by humans is a unique form where he can put himself in accordance with the which he Believed; awareness shows us how to act in accordance with the existing reality. If the taxpayer realizes the importance of paying taxes to fund government spending and national development and therefore the taxpayer does not feel disadvantaged by the tax or do not feel that the tax is a burden that would reduce Reviews their income, so as to encourage people to Participate and Realize Reviews their responsibilities as required tax compliant.

Another factor that may Affect the taxpayer compliance is a tax penalty. In terms of tax, said that taxes have properties that are enforceable under the law, then there are legal consequences if it does not obey or adhere to such laws. The consequence of this law is the imposition of sanctions roommates were made with the aim that Taxpayers are afraid to violate tax laws. Tax penalty is a guarantee that the provisions of tax legislation (taxation norms) will be Followed / obeyed / Followed. Or in other words the tax penalty is a tool (preventive) so that the taxpayer does not violate the norms of taxation [5]. Based on the description above, the writer sets the title Research on tax compliance have been Carried out.

According to [3] tax compliance is mandatory tax prescribed by the Director General of Taxation as a taxpayer who meets Certain criteria can be given a preliminary return of overpaid taxes. According to Suryadi [4] tax compliance established by the dimensions of the tax inspection, enforcement and compensation tax. The purpose was to test the examination of tax compliance in implementing the tax. Increase tax compliance obligations state and in turn will increase of the size of the tax rate [5]. Based on the description above, the writer sets the title " The Influence of Tax Comprehension, Tax Awareness and Tax Sanctions Towards Tax Obedience of MSME".

\section{RESEARCH METHODS}

This type of research is quantitative research. Quantitative research is a research method that is based on the philosophy of positivism in the underlying figures with statistics management. Secondary sources of data were used in this research is the source of the data Obtained through the literature, the internet media. The study population was taxpayer MSME registered in the STO Metro as many as 3.329 people to conduct business online-based criteria.
Sampling using convenience sampling method is the method of sampling freely and without Specifying conditional status, or the circumstances of the respondent making Researchers convenient and easy to take samples. The number of samples taken in this study using Slovin formula is:

$$
\mathrm{n}=\frac{\mathrm{N}}{1+\mathrm{NE} 2}
$$

Samplers comprise less than 97 respondents having already represented the total number of samples where the sample is taken to represent a wide range of MSME taxpayer in Metro City.

\subsection{Requirements Test Instruments}

\subsubsection{Validity Test}

Significance testing is done by comparing the value of $r$ count $r$ table for degree of freedom $(\mathrm{df})=\mathrm{n}-2$, in this $\mathrm{n}$ is the number of samples. The question is not valid if $r$ arithmetic (each item can be seen in Colom corrected correlation -Total 60 item) greater than $r$ table and the value of $r$ is positive then the statement declared invalid.

\subsubsection{Reliability Test}

Reliability testing using Cronbach Alpha coefficients with SPSS, a question can be Considered reliable if the alpha value is greater than the critical value (0.7). If the value of reliability of less than $(0.7)$, then the value is less good.

\subsection{Classical Assumption Test}

\subsubsection{Normality test}

The basic decision to test the data normality Kolmogorov known through with Sig-Smirnov test (two-tailed) $>0.05$.

\subsubsection{Multicollinearity Test}

Multicoloniarity can be viewed by using the values of tolerance and Variance Inflation Factor (VIF). Tolerance measures the variability of the independent variables were selected that is not Described of other variables, the tolerance value lower or equal to the value of VIF. The cutoff values used to show reviews their multicollinearity is Tolerance value $\leq 0: 10$, or equal to the value of VIF $\geq 10$.

\subsection{Autocorrelation Test}

Autocorrelation test: The test is done by testing regressed Glejser the independent variables on the residual variable absolute significance of $5 \%$, if there is no statistically significant variables that do not contain heteroskedastic regression [6]. 


\subsection{Accuracy Test Model}

\subsubsection{T test}

$\mathrm{T}$ test was used to compare $\mathrm{t}$ with ttable. If $\mathrm{t}>\mathrm{t}$ table it can be concluded that partially Significantly independent variables influence the dependent variable [7].

\subsubsection{F test}

The F statistic is used to see Whether the regression models used is fixed or not, with the provision that if the $\mathrm{p}$ value $>$ (a) $=0: 05$ and $F$ count $>F$ table. With a confidence level to test the hypothesis of $95 \%$ [6].

\subsubsection{Test Coefficient of Determination R2}

R2 small value means the ability of independent variables in explaining the dependent variable are very limited. A value close to 1 means significant independent variables give all the information needed to predict the dependent variable.

\subsection{Multiple Linear Regression Analysis}

Regression analysis is basically the study of the dependence of the dependent variable (bound) with one or more independent variables (explanatory variables / free) is used to test the hypothesis that has been chosen. The equation is as follows:

$\mathrm{Y}=\alpha+\beta_{11}+\beta_{2.7}+\mathrm{B} 3 \mathrm{X} 3+\beta 4 \mathrm{X} 4+\mathrm{e}$

\subsection{Hypothesis}

a. When the number of degrees of freedom (df) is 20 or more and 5\% confidence level it can be concluded that the independent variables Affect the dependent variable. Comparing the value of $t$ statistics with critical points According to the table.

b. If the value Tcount $>$ TTable value, then the alternative hypothesis states that an individual roommates' independent variables Affect the dependent variable.

\subsection{Statistical Hypotheses}

Statistical Hypotheses are allegations or statements that need to be tested were correct. Based on this, the hypothesis of this study is:

a. Ho: $\mathrm{b} 1 \leq 0=$ Understanding the taxpayer $(\mathrm{X} 1)$ has no effect on tax compliance $(\mathrm{Y})$

b. Ha: $\mathrm{b} 1 \geq 0=$ Understanding the taxpayer (X1) effect on tax compliance $(\mathrm{Y})$

c. Ho: $\mathrm{b} 2 \leq 0=$ Awareness taxpayer (X2) has no effect on tax compliance $(\mathrm{Y})$ d. Ha: b3 $\geq 0=$ Awareness taxpayer (X2) effect on tax compliance $(\mathrm{Y})$

e. Ho: $\mathrm{b} 3 \leq 0=$ Penalties Tax (X3) had no effect on tax compliance $(\mathrm{Y})$

f. Ha: $\mathrm{b} 3 \geq 0=$ Penalties taxes (X3) on tax compliance (Y)

\section{RESULTS AND DISCUSSION}

\subsection{Descriptive Respondents by Gender}

Table 1 Descriptive Respondents by Gender

\begin{tabular}{|lll|}
\hline Gender & Frequency & Presentation \\
\hline Man & 28 & $28.9 \%$ \\
\hline woman & 69 & $71,1 \%$ \\
\hline Total & 97 & $100 \%$ \\
\hline
\end{tabular}

Sources: Processed Primary Data in 2019

Based on Table 1 can explain that the questionnaire that was distributed as much as 97 respondents consisted of 28 men and 69 women.

\subsection{Respondents by descriptive Taxpayers}

Table 2 Respondents Based on the Old Taxpayers

\begin{tabular}{|lll|}
\hline level of effort & Frequency & Presentation \\
\hline $\mathbf{1 - 5}$ & 50 & $51.5 \%$ \\
\hline $\mathbf{6 - 1 0}$ & 34 & $35.1 \%$ \\
\hline $\mathbf{1 1 - 1 5}$ & 8 & $8.2 \%$ \\
\hline$>\mathbf{1 5}$ & 5 & $5.2 \%$ \\
\hline Total & 97 & $100 \%$ \\
\hline $\mathbf{1 - 5}$ & 50 & $51.5 \%$ \\
\hline $\mathbf{6 - 1 0}$ & 34 & $35.1 \%$ \\
\hline $\mathbf{1 1 - 1 5}$ & 8 & $8.2 \%$ \\
\hline$>\mathbf{1 5}$ & 5 & $5.2 \%$ \\
\hline Total & 97 & $100 \%$ \\
\hline
\end{tabular}

Respondents longer registered as taxpayers around 1-5 years.

\subsection{Descriptive Statistics}

Table 3 Descriptive Statistics

\begin{tabular}{|c|c|c|c|c|}
\hline & $\mathbf{X 1}$ & $\mathrm{X} 2$ & $\mathrm{X3}$ & $\mathbf{Y}$ \\
\hline valid & 97 & 97 & 97 & 97 \\
\hline \multirow{2}{*}{$\begin{array}{l}\mathrm{N} \\
\text { missing } \\
\text { mean }\end{array}$} & 0 & 0 & 0 & 0 \\
\hline & 28.6495 & 20.6082 & 20.6598 & 27.7113 \\
\hline Std. deviation & 3.24050 & 2.19164 & 2.05085 & 3.22089 \\
\hline Range & $16: 00$ & $9: 00$ & 8:00 & $16: 00$ \\
\hline Minimum & $18: 00$ & $15: 00$ & $17: 00$ & $18: 00$ \\
\hline maximum & 34.00 & 24.00 & 25.00 & 34.00 \\
\hline Sum & 2779.00 & 1999.00 & 2004.00 & 2688.00 \\
\hline
\end{tabular}

Sources: Primary Data is processed in 2019

Based on the above statistical tests, it can be seen that the variable understanding of the taxpayer has a minimum 


\subsubsection{The Reliability Test}

value of 18 , the maximum value of 34 and the average value $=28.6495$ with a standard deviation of 3.24050 . Variable awareness of the taxpayer has a minimum value of 15 , the maximum value of 24 and the average value with a standard deviation of 20.608232 .19164 . Variable tax penalties have a minimum value of 17 , the maximum value of 25 and the average value of 20.6598 with a standard deviation of 2.05085. Variable tax compliance has a minimum value of 18 , the maximum value of 34 and the average value of a standard deviation of 3.2208927 .7113 .

\subsection{Test Research Instruments}

Analysis of the Data of instrument testing in this study include the validity and reliability. The result can be seen one by one from the processing of Spss as follows:

\subsubsection{Validity Test}

Significance test is done by comparing the value of $r$ count $r$ table, where r-table can be obtained by df (degree of freedom $)=\mathrm{n}-2$ (significant $5 \%)$. In this study, $\mathrm{df}=\mathrm{n}-2=$ $97-2=95$ in order to get a table for $\mathrm{df} r(95)=0199$. Based on the analysis performed, the results of testing the validity of all values of $r$ calculated for each statement is greater than $\mathrm{r}$ table. This means that each statement in this study is valid.

Table 4 Tax Comprehension, Awareness and Tax Tax Tax Sanctions Towards Obedience of MSME

\begin{tabular}{|c|c|c|c|c|}
\hline variables & item & $\begin{array}{c}\mathbf{r} \\
\text { arithmetic }\end{array}$ & $R$ table & $\begin{array}{c}\text { Gathering } \\
\text { of }\end{array}$ \\
\hline \multirow{7}{*}{$\begin{array}{l}\text { comprehension } \\
\text { compulsory } \\
\text { Tax } \\
\text { (X1) }\end{array}$} & $\mathrm{X} 1.1$ & 0,478 & 0199 & valid \\
\hline & $\mathrm{X} 1.2$ & 0507 & 0199 & valid \\
\hline & $\mathrm{X} 1.3$ & .437 & 0199 & valid \\
\hline & $\mathrm{X} 1.4$ & 0627 & 0199 & valid \\
\hline & $\times 1.5$ & 0405 & 0199 & valid \\
\hline & $\mathrm{X} 1.6$ & 0423 & 0199 & valid \\
\hline & $\mathrm{X} 1.7$ & .557 & 0199 & valid \\
\hline \multirow{5}{*}{$\begin{array}{l}\text { Mandatory } \\
\text { awareness } \\
\text { Tax } \\
\text { (X2) }\end{array}$} & $\mathrm{X} 2.1$ & 0426 & 0199 & valid \\
\hline & $\mathrm{X} 2.2$ & 0299 & 0199 & valid \\
\hline & $\mathrm{X} 2.3$ & 0317 & 0199 & valid \\
\hline & $\mathrm{X} 2.4$ & 0432 & 0199 & valid \\
\hline & $\mathrm{X} 2.5$ & 0423 & 0199 & valid \\
\hline \multirow{5}{*}{$\begin{array}{l}\text { Sanctions } \\
\text { Tax } \\
\text { (X3) }\end{array}$} & X3.1 & 0,243 & 0199 & valid \\
\hline & $\mathrm{X} 3.2$ & 0.363 & 0199 & valid \\
\hline & X3.3 & 0273 & 0199 & valid \\
\hline & X3.4 & 0360 & 0199 & valid \\
\hline & $\mathrm{X} 3.5$ & 0326 & 0199 & valid \\
\hline \multirow{7}{*}{$\begin{array}{l}\text { Mandatory } \\
\text { compliance } \\
\text { Tax } \\
\text { (Y) }\end{array}$} & Y1 & 0634 & 0199 & valid \\
\hline & Y2 & .549 & 0199 & valid \\
\hline & Y3 & .417 & 0199 & valid \\
\hline & Y4 & 0361 & 0199 & valid \\
\hline & Y5 & 0504 & 0199 & valid \\
\hline & Y6 & 0,478 & 0199 & valid \\
\hline & Y7 & 0634 & 0199 & valid \\
\hline
\end{tabular}

Source: The results of data processing
Table 5 The reliability Test Results

\begin{tabular}{|llll|}
\hline variables & $\begin{array}{c}\text { Cronbach's } \\
\text { Alpha }\end{array}$ & $\begin{array}{c}\text { critical } \\
\text { value }\end{array}$ & information \\
\hline Y & 0,782 & 0.7 & reliable \\
\hline X1 & 0768 & 0.7 & reliable \\
\hline X2 & 0725 & 0.7 & reliable \\
\hline X3 & 0752 & 0.7 & reliable \\
\hline
\end{tabular}

Based on the above table it can be seen that, of all the variable values indicate that the Cronbach Alpha coefficients $>0.6$ so that it can be concluded that all the instruments in this study is reliable.

\subsection{Ordinary Least Square}

\subsubsection{Normality test}

The statistical test used to test the normality is the nonparametric statistical tests Kolmogorov-Smirnov. Judging from the resulting significance of $>0.05$, then the distribution of data is said to be normal. Conversely, if the significance $<0.05$ then it is not normally distributed. Normality test results can be seen in the following table:

Table 6 Normality test

\begin{tabular}{|c|c|}
\hline & $\begin{array}{l}\text { Residual } \\
\text { unstandardized }\end{array}$ \\
\hline mean & 86 \\
\hline Normal & .0000000 \\
\hline Parameters a ,, b Std. deviation & 1.85503340 \\
\hline Most Extreme Positive Absolute & .085 \\
\hline Differences & .085 \\
\hline negative & -.058 \\
\hline Kolmogorov-Smirnov Z & .792 \\
\hline Asymp. Sig. (2-tailed) & .557 \\
\hline
\end{tabular}

Source: The results of data processing

From the above table normality test results KolmogorovSmirnov stated value of 0792 with 0.557 significant. Based on these results it can be stated that the data used in this study had normal distribution and can be continued because of the significant value of the normality test $>0.05$.

\subsubsection{Test Results Multicollinearity}

Multicollinearity test done by looking at the value of tolerance and variance inflation factor (VIF). If the tolerance value is greater than 0.1 and VIF is less than 10 , then the data is free from multicollinearities case. Multicollinearity test results can be seen in Table 7 . 
Table 7 Test Multicollinearity

\begin{tabular}{|c|c|c|}
\hline \multirow[t]{2}{*}{ Model } & \multicolumn{2}{|c|}{ collinearity Statistics } \\
\hline & tolerance & \\
\hline \multicolumn{3}{|l|}{ (Constant) } \\
\hline Understanding Taxpayers & 298 & 3,353 \\
\hline Tax awareness & .335 & 2,986 \\
\hline Tax Penalties & .719 & 1391 \\
\hline
\end{tabular}

Source: The results of data processing

From the above table, it can be seen that the VIF for all independent variables $<10$ and so also for tolerance values $>$ 0.10 . It can be concluded that the regression model is free of multicollinearity.

\subsubsection{Autocorrelation Test Results}

In this study, the autocorrelation is detected by the DurbinWatson value. Limit non-occurrence of autocorrelation is the Durbin-Watson numbers are between -2 up to +2 .

Table 8 Test of autocorrelation

\begin{tabular}{|ccrrrr|}
\hline $\begin{array}{c}\text { Mo } \\
\text { del }\end{array}$ & R & R Square & $\begin{array}{c}\text { Adjusted } \\
\text { R Square }\end{array}$ & $\begin{array}{c}\text { Std. } \\
\text { Error of } \\
\text { estimate }\end{array}$ & $\begin{array}{c}\text { Durbin- } \\
\text { Watson }\end{array}$ \\
\hline $\mathbf{1}$ & $.754 \mathrm{a}$ & .568 & .547 & 1.90028 & 1,926 \\
\hline
\end{tabular}

source: The results of data processing

Based on the above table can be seen the value of the Durbin-Watson statistic for 1,926. With inequality -2 $<1,926<+2$, then could concluded regression model free from the influence of autocorrelation.

\subsubsection{Results of Multiple Regression Analysis}

Table 9 Regression Analysis

\begin{tabular}{|c|c|c|c|c|c|}
\hline \multicolumn{6}{|c|}{ Coefficients } \\
\hline \multirow[t]{2}{*}{ Model } & \multicolumn{2}{|c|}{$\begin{array}{l}\text { coefficients } \\
\text { unstandardized }\end{array}$} & $\begin{array}{l}\text { standardized } \\
\text { Coefficients }\end{array}$ & $\mathrm{t}$ & Sig. \\
\hline & B & $\begin{array}{l}\text { Std. } \\
\text { Error }\end{array}$ & beta & & \\
\hline (Constant) & 7.267 & 2,654 & & 2,738 & .007 \\
\hline $\begin{array}{l}\text { Taxpayers } \\
\text { understan } \\
\text { ding }(\mathrm{X} 1)\end{array}$ & .692 & .129 & 697 & 5.364 & .000 \\
\hline $\begin{array}{l}\text { Tax } \\
\text { awareness } \\
\text { (X2) }\end{array}$ & -.181 & .180 & -.123 & -1006 & .317 \\
\hline $\begin{array}{l}\text { Tax } \\
\text { Penalties } \\
\text { (X3) }\end{array}$ & -.065 & .131 & -.042 & -.498 & .620 \\
\hline
\end{tabular}

Source: The results of data processing

Based on the results of the regression at 3.8 in the above table, the linear regression equation in this study can be written as follows:

$$
\mathrm{Y}=7,267+0,692 \times 1-0,181 \times 2-0,065 \times 3+e
$$

\subsubsection{Feasibility Testing Model Result}

Table 10 Coefficient of Determination

\begin{tabular}{|lrrrrr|}
\hline $\begin{array}{l}\text { Mo } \\
\text { del }\end{array}$ & $\mathbf{R}$ & $\begin{array}{c}\text { R } \\
\text { Square }\end{array}$ & $\begin{array}{l}\text { Adjusted } \\
\mathbf{R} \\
\text { Square }\end{array}$ & $\begin{array}{l}\text { Std. Error of } \\
\text { estimate }\end{array}$ & $\begin{array}{c}\text { Durbin- } \\
\text { Watson }\end{array}$ \\
\hline $\mathbf{1}$ & $.754 \mathrm{a}$ & .568 & .547 & 1.90028 & 1,926 \\
\hline
\end{tabular}

Source: The results of data processing

According to the table above, note the value of Adjusted R2 of 0.547 . What this means is that the contribution of the influence of independent variables on the dependent variable is equal to $54.7 \%$. While the remaining $45.3 \%$ is influenced by other variables not included in this regression model.

\subsection{6. test $F$}

Table 11 test F

\begin{tabular}{|c|c|c|c|c|c|c|}
\hline \multicolumn{2}{|c|}{ Model } & \multirow{2}{*}{$\begin{array}{c}\begin{array}{c}\text { Sum of } \\
\text { Squares }\end{array} \\
15617\end{array}$} & \multirow{2}{*}{\begin{tabular}{|c|} 
df \\
4
\end{tabular}} & \multirow{2}{*}{$\begin{array}{l}\text { mean } \\
\text { Square } \\
3,904\end{array}$} & \multirow{2}{*}{$\begin{array}{c}\mathbf{F} \\
1902\end{array}$} & \multirow{2}{*}{$\begin{array}{l}\text { Sig. } \\
.017 \mathrm{~b}\end{array}$} \\
\hline 1 & Regression & & & & & \\
\hline & residual & 188819 & 92 & 2,052 & & \\
\hline & Total & 204436 & 96 & & & \\
\hline
\end{tabular}

Source: The results of data processing

Based on the results of the above table shows the value of output sig Fcount 1,902 and 0,017 less than 5\%. Furthermore, comparing Fcount with Ftabel. (At 0:05 df Obtained Ftable value $=1.77)$ that $F$ count $>F$ table $(1.902>$ 1.77), it can be concluded that the taxpayer Understanding, Awareness of Tax and Tax Sanctions simultaneously influence taxpayer compliance SMEs in STO Metro. This means that the regression models used is feasible or Appropriate.

\subsection{7. t test}

Hypothesis testing is partially done with comparing the value of $t$ arithmetic with $t$ table. $T$ table at a significance level of 5\%. Based on the analysis in Table, it can be seen the influence of independent variables on the dependent variable partially to the following description:

a. Taxpayers understanding Obtained value of $t=5,364$, and the probability of 0000 using a 0:05 significance limit $(\alpha=5 \%)$, Obtained TTable $(1,660)$. This means that $5,364>1.660$ and $0.000>0.05$. This shows that the understanding Over Tax Payment Mechanism significant impact on taxpayer compliance MSME in STO Metro.

b. Obtained values Variable Tax Awareness $t=-1006$ and a probability of 0.317 , using a 0:05 significance limit $(\alpha$ $=5 \%$ ), Obtained TTable $(1,660)$. This means -1006 $<1.660$ and $0.317<0: 05$. This indicates Tax Awareness no effect on tax compliance STO MSME in Metro.

c. Tax Penalties Obtained variable values $t=-0498$ and a probability of 0620 , using a 0:05 significance limit $(\alpha=$ $5 \%$ ), Obtained TTable $(1,660)$. This means $-0498<1.660$ and $0620<0: 05$. This suggests that the tax penalty has no effect on tax compliance STO MSME in Metro. 
[3] Gregorio Giménez; (2017), The Impact of the Patent System on the Social Welfare: A Critical View, Intangible Capital - https://doi.org/10.3926/ic.789.

Based on research on the understanding of the Taxpayer Awareness Tax, Tax Compliance Taxpayer Sanctions against STO MSME in Metro, it can be concluded as follows: Taxpayers understanding significant impact on taxpayer compliance MSME in STO Metro. So, the greater understanding of the taxpayer who has given it to Increase knowledge of the taxpayer that will improve compliance taxpayer MSME in STO Metro.

Awareness Tax effect on tax compliance STO MSME $s$ in Metro. Awareness of the taxpayer Taxpayers understand the tax system is used, Determine the tax function as a source of state revenues used for financing the country, as well as understand the tax laws regarding charging the tax return and pay tax obligations. So, the higher awareness of tax payers would SMEs increase of taxpayer compliance.

Tax sanctions have no effect on tax compliance STO MSME in Metro. So, the Tax Sanctions Adopted by the Government has not gone well, so that tax Reviews their penalties do not Affect compliance taxpayer SMEs

\section{REFERENCES}

[1] Albert G.Z. Hu and I.P.L. Png, (2013), Patent Rights and Economic Growth: Evidence from CrossCountry Panels of Manufacturing Industries, Oxford Economic Papers, doi:10.1093/oep/gpt011.

[2] Dirk Czarnitzki and Andreas Fier, (2004), Publicly Funded R\&D Collaborations and Patent Outcome in Germany, Discussion Paper No. 03-24.
[4] Nicolas van Zeebroecko, Bruno van Pottelsberghe de la Potterie $\alpha$ and Dominique Guellec, (2008), Patents and Academic Research: A State of the Art, the Journal of Intellectual Capital, Volume 9, Issue 2, 2008.

[5] Raul Kartusa and Ants Kukrus, (2013), Innovation, Product Development and Patents at Universities, Estonian Journal of Engineering, 2013, 19, 1, doi: 10.3176/eng.2013.1.02.

[6] Rifat Atun, (2006), Innovation, Patents and Economic Growth, International Journal of Innovation Management.

https://www.researchgate.net/publication/23751118, diakses tanggal 18 Oktober 2019.

[7] Wenkai Tzeng, (2017), Poverty and Patents: Intellectual Property Policy and Economic Inequality, Indiana Journal of Law and Social Equality, Vol 5 Issue 2.

[8] Van Roy, Vincent and Vertesy, Daniel and Vivarelli, Marco, The Job-Creation Effect of Patents: Some Evidence from European Microdata (April 2016). Available at SSRN: https://ssrn.com/abstract=2770525 or http://dx.doi.org/10.2139/ssrn.2770525 